\title{
HOW CAN WE DEVELOP A MORE FUNCTIONAL CITIZENSHIP PROGRAM?
}

Chairman: Herndon C. Ray, Co-ordinator of Secondary Education, Stanislaus County Schools, Modesto, California

INTERROGATORS AND CONSULTANTS:

Sister Mary Janet, S.C., Secondary Curriculum Consultant, Commission on American Citizenship, Catholic University of American, Washington, D. C. H. L. Rebbe, Principal, Powell High School, Powell, Wyoming

\section{Summary of a presentation by ODINA B. OLSON}

B the 1952 meeting of the National Association of Secondary-Schools Principals in Cincinnati a year ago. Printed in the convention proceedings BULLETIN were papers prepared by Frank Peake of Shades Valley High School, Birmingham, Alabama, and Theodore Mayer of the Columbus, Ohio, Public Schools, defining the characteristics of citizenship. With such excellent presentations as these, it seems unnecessary to restate them; therefore, the remarks in this paper will be devoted to a description of the program of one school; namely, the University of Michigan High School. A functioning citizenship program requires four elements:

1. Agreement on what citizenship is

2. Citizenship practiced and exemplified by the teachers

3. Opportunity for pupils to learn through experience

4. Availability and effective use of all resources

\section{Agreement on what citizenship is}

In coming to an agreement of what citizenship is, the pupils, teachers, and parents worked together to revise the method of reporting citizenship. Pupils in the school divided into random groups to discuss what a good school citizen is. The notes from these groups were turned over to a committee which, after reviewing them with teachers and parents, formulated the school definition of citizenship under six main headings: ${ }^{1}$
a. Consideration for others
b. Co-operation
c. Dependability
d. Efficient workmanship
e. Initiative in thought and action
f. Integrity

${ }^{1}$ A more complete description of the procedure can be had by writing to the University High School, Ano Arbor, Michigan.

Odina B. Olson is Assistant Principal of University High School, Ann Arbor, Michigan. 


\section{Citizenship practiced and exemplified by the teachers}

Citizenship is mainly a matter of attitudes which are caught rather than taught; therefore, we believe it is necessary to have on our staff teachers who exemplify the qualities we wish to develop in the student body.

\section{Opportunity for pupils to learn through experience}

Like any other learning, pupils must learn to be good citizens through experience. We believe that students should be allowed to "take the controls" in managing student affairs when they are ready and capable of so doing; that pupils who are busy developing school projects will work for the good of the school, and in their pride of accomplishment be unwilling to commit acts which will be detrimental to the spirit of the school or destructive to the physical plant.

\section{Availability and effective use of all resources}

Perhaps the most obvious resource for the learning of citizenship is to be found in the student council and its many offices, committees, and sponsored clubs. These all serve as training areas for developing on the part of the individual pupil the responsibility of supporting those he elected, and developing on the part of each officer a sense of responsibility to the student body which chose him. All schools have resources available for practicing citizenshipperhaps more than they can use. At University High School, other effective resources besides the ones stated above are found to be:

(1) The home room-For instance, in the area of "developing consideration for others," when one home-room group wished to have a Christmas party, draw names and give each other presents, instead of keeping the gifts, the pupils rewrapped them and took them to the children's ward at the hospital. Thereafter, this group on succeeding Christmas seasons either donated money for CARE packages, provided dinners for needy families, sent a Christmas package to a Finnish war orphan, or supplied the money for milk to be delivered to a needy family for several months.

(2) Assemblies-Besides the regular planned weekly assembly provided or sponsored by some student group, we believe that it is healthy to call an occasional special assembly to acquaint the students with some problem that seems of vital concern to us. This problem is then clearly explained so that the issue is understood, and a discussion period in home room immediately follows the assembly where suggestions for a solution to the problem are made. For example, the telephone that is provided for the use of the pupils was recently damaged; two or three replacements of the directory had been made. The principal of the school called a special assembly where the torn book was displayed, the cost of providing the telephone was explained, and the statement made that the simplest solution to the problem would be to take out the phone. But since only five or six pupils at the most were responsible for the destruction, it seemed hardly fair to deprive the entire student body of the use of the telephone because 
of the thoughtlessness of so few. Pupils were asked to discuss the problem in home room, and to send to the office suggestions for a remedy. It was also pointed out that it was possible that other areas for improvement could well be discussed.

(3) Leadership group meetings can be effective in developing a functional citizenship program-for instance, we think it is wise once or twice a year to invite the student leaders of the school to a meeting where general school policies or specific problems are discussed. We include all of those who have real leadership in the sense that they have influence over a significant number of students. This includes not only those who are constructive but also those whose leadership may be subversive, obstructive, or merely manifestations of social or civic awkwardness. The aim would be to develop unwise leadership into wholesome and constructive leadership and to direct effectively the energy and initiative of these pupils so endowed toward the improvement of the school. Such a meeting we try to hold outside of our building for a half or even a whole day of school time. Similar illustrations are available for use of other resources which include class clubs, such as Latin, French, Spanish, science, and music; the school publications such as the newspaper and the literary magazine; dramatic productions, with stage and other production crews; the school publicity commitree which enlists the work of the art and journalism departments; the athletic organizations which have team members, managers, ticket salesmen, cheerleaders, and boosterclub personnel; office club and library club, and cafeteria and social committees. We have found that the less that citizenship is talked about and the more opportunities there are for experiencing the acts of good citizenship, the better the results will be. We have learned that this is accomplished best by working with small groups. An individual cannot isolate himself from active participation or enjoy the anonimity provided by a large group if he is identified as a member of a small group where he must do his share. It is our aim that every pupil in University High School should experience the pride and satisfaction that comes from doing some out-of-class activity that is recognized by his associates as worth while. We believe we effect a more functional citizenship program in our school by working with students using the same democratic principles we use with the teaching staff.

\section{Summary of a presentation by HOWARD M. CARR}

$\mathrm{T}$ sponsibilites of cirizenship is as old as the tecods of civilizaton. The methods sponsibilities of citizenship is as old as the records of civilization. The methods and processes employed in this vital education have changed with the changing social order.

Now it seems to me the common denominator in the training in these past social orders was first a period of observation, then fringe participation, and

Howard M. Carr is Principal of the Stadium High School, Tacoma, Washington. 
finally the prearranged or accidental event which proved or disproved the worthiness of the candidate. In short, the preparation was participation in the real thing. The continental system of apprenticeships and indentures followed a similar pattern.

We in our schools find ourselves almost completely relying on vicarious experiences and in many instances only a textbook recounting of what the prospective citizen should possess in information and skills. The first actual participation in the affairs of nation, state, and community often comes with the arrival of that twenty-first birthday. We as educators well realize that no one day in the life of all people can be chosen as a measure of universal readiness for any given responsibility. To be sure we have used every conceivable device and artifice to simulate the real life experiences of citizenship. We have student governments and annual visits to the city hall, the county court house, and invite available officials to speak to class groups, etc.; thereby we attempt to tie our textbook learning to the real thing. Well, where do we get? What does the record say about the active participation of the citizens we have produced in the past ten or twenty years? What percentage of them are fulfilling their minimum obligations of expressing themselves at the polls? To be sure we have shouldered them with the obligation of wars to defend a democratic social order in which many of them have never participated in the other duties of citizenship.

It would appear that I am carrying a torch for earlier enfranchisement. No, that is nor my contention. I would claim, frrst, that we are not doing the job we must do if real democracy is to survive and that the records show this; second, that early and continuous participation in the actual, the real, the earnest, the immediate community problems is the best indoctrination for the challenge and obligation of that twenty-first birthday; third, that the methods of our distant ancestors had some elements which can be adapted to our complex social order.

Some ten years ago we felt the need of some revision of the instruction for citizenship. We made a comprehensive survey of the entire social studies area from the first through twelfth grade. We revised the whole course of study; we articulated here and correlated these; we adopted new textbooks.

We were not satisfied with those for some grade levels, so we wrote some of our own. Well, believe me, when we finished it was really fancy-no flaws in this and all accomplished by a very, very democratic procedure. Yes sir, the teachers did it all. Oh! it was a beautiful thing with lesson plans, teacher guides, reference shelves, and audio-visual aids all keyed to the exact instant of readiness. The only trouble was we did not seem to be producing a better, more actively participating citizen.

Don't misunderstand me. We have a good course of study. I would even be so bold as to boast that it has better horizontal and vertical articulation than the average in use today. We have had requests from all over the country for copies of the syllabus. But more of the same or even better organization of the same is not enough. 
Now, on my faculty, I have a couple of unorthodox, unconventional souls in the social studies department. Some years ago they surreptitiously-and I use the word advisedly - began some practices which were quite unethical for our course of study. In their civics classes they began a study of some of the controversial problems of our community. For example, they actually encouraged their students to question and challenge the methods employed by the city fathers in handling and conducting the parks and playgrounds of our city. They succeeded in arousing the interest of a few parents and disturbing the equanimity of the park board and city commissioners. I doubt if today these students of yesteryears realize that from this beginning and their continued fringe participation and later active participation as mature citizens there evolved a somewhat unique union of many agencies to foster and maintain an extensive winter and summer recreation program for all age groups. A director was obtained whose work has been so outstanding that his services have been borrowed by several other cities and, during the last year, by the Federal government to survey the youth recreational activities in occupied Germany.

What a calamity resulted! While these groups were spending their time participating in community affairs the other classes got clear over to page 392 in Magruder's American Government, right smack dab in the middle of a chapter on civil rights. At the end of the year we gave all classes a standard test and were greatly relieved to find that these experimental classes did as good as the other classes in areas which had not been formally taught and went way off the scale in the areas where there had been fringe participation.

In later years we surreptitiously entered some other areas for fringe participation-one of them the care and housing of delinquent minors.

Eventually through our membership in the Associated Public Schools of America, we learned of and were invited to participate in the Citizenship Education Project. Here, in brief, are the essentials: (1) Financed first with a $\$ 500,000$ grant from Carnegie, later raised to $\$ 1,500,000$. (2) Organized to experiment with more effective ways of teaching citizenship. (3) Administered by General Eisenhower, then President of Columbia University and the prime mover in the experiment.

We were relieved to find that what basically the procedure CEP recommends is similar to that our own furtive and fumbling efforts had devised. They, too, use participation as the most effective way of training for functional citizenship. Carefully directed experiments enable them to set up teacher and pupil guides and to provide a catalogue of references and resources that are of inestimable value.

We do not throw textbooks out the window. Far from it. We have more books, and they are used more than ever before. Our library, too, has added new material and circulation has increased.

May I now recount for you some of our experiences under the helpful direction of the Citizenship Education Project. 
Tacoma's city government derived its authority from a charter which had not been revised or even reviewed for many years. A Board of Freeholders was selected to study and recommend revisions. They were confronted with a problem. What kind of government did the people of the city want?

Students planned to survey the people to determine how the people felt about the situation and what they wanted done. They compiled a questionnaire to find out: (1) Were people satisfied with the present form of government? (2) How well informed were they on the various forms of city government? (3) What form of government did they choose to have?

They selected a committee of citizens to criticize the questionnaire and make suggestions and approve the final document of three pages and some twentyfour questions. They obtained the expert advice of statisticians from the State University on methods of conducting a sample poll and set up a procedure which these experts reviewed and agreed would be reliable. They then interviewed some 333 people. These individuals covered a typical cross section of the city. The findings were then reviewed by the classes and the citizens committee. The results were made available to the Freeholders Board, published through the press, radio, and by drama and recordings, at group meetings and service clubs.

Action! The Board of Freeholders drew up and placed on the ballot a new charter incorporating the form of government the survey found most desired. It was presented to the voters at the November election, 1952, and approved by almost the same majority the student poll had predicted.

What was public reaction? Mr. Average Citizen was somewhat startled to find the interest and information of youth greater than that of himself. It provoked a marked increase in public interest in the proposed change.

What did students think of the experience? Here is the reply of one girl: "If our class lost anything from just studying, we gained several fold more in our experience in active government. We learned to study a report on government and realize its true value. I believe every one of us worked harder and thought more and learned more than we ever could from just studying the same thing from a book. We certainly enjoyed working with that Citizens Committee."

We have, of course, conducted many other projects with varying degrees of success. None of them has ever been rated by the students as a waste of time or unprofitable.

We, of course, had political conventions in the spring of 1952. Members of both Democratic and Republican local committees assisted in planning and operating this all-school project. It resulted in a better pupil understanding of the two party system and general approval of the system. This latter was somewhat impaired as they later saw the two conventions on television. The reaction was typefied by the statement of one boy, "Why, Mr. Carr, that was a mess; it was just a riot. They didn't know what they were doing. Why can't they run 
orderly, dignified conventions like we did. Do you think our country can retain the respect of its people when the leaders are selected like that?"

We are setting up a project now that involves participation in the selection of a site for a proposed city county building. Officials have enthusiastically welcomed our assistance in evaluating the data collected on the merits of the nine possible sites. After all, it is the high-school students of today who will use and pay for this building.

The selection of a project or practice always poses a major difficulty. We have found that those which originate from the normal classroom discussions are most desirable. It need not be large in scope but must contain, first, participation which projects into the community life in some phase and, second, must result in some action or accomplishment in this area.

\section{WHAT ARE PROMISING ADMINISTRATIVE PRACTICES IN THE SENIOR HIGH SCHOOL?}

Chairman: Lloyd N. Morrisett, Professor of Education, University of California, Los Angeles, California

INTERROGATORS AND CONSULTANTS:

The Rev. Kenneth P. Evans, Principal, Lunenburg High School, Victoria, Virginia

Charles Secoy, Principal, Troy High School, Troy, Ohio

\section{Summary of a presentation by REX K. JOHN (The Student Exchange Program)}

卫

HE student exchange idea is not new. For several years a few high schools in the eastern part of the United States have carried on student exchanges with high schools in nearby states. Such exchanges have enabled groups of students from one community to become acquainted with groups of students from other communities, to discover fot themselves ways in which they are similar or unlike, and to see at first hand conditions under which young people like themselves live. Undoubtedly one basic belief underlying the whole student exchange idea is the firm conviction that national unity can best be promoted through a better common understanding of the beliefs and customs of widely separated regions and that there is no satisfactory substitute for individual and group contacts.

Our first experience in student exchanges was obtained last year when such a project was arranged with the Miller and Lanier Senior High Schools of Macon,

Rex K. John is Principal of Lincoln High School, Manitowoc, Wisconsin. 